\title{
Anaerolineaceae and Methanosaeta turned to be the dominant microorganisms in alkanes-dependent methanogenic culture after long-term of incubation
}

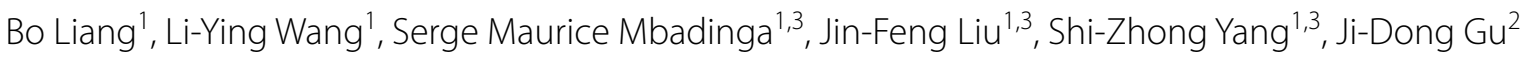
and Bo-Zhong $\mathrm{Mu}^{1,3^{*}}$

\begin{abstract}
The methanogenic alkanes-degrading enrichment culture which had been incubated for over 1,300 days amended with $n$-alkanes $\left(C_{15}-C_{20}\right)$ was investigated through clone libraries of bacteria, archaea and ass $A$, mcrA functional genes. These enrichment cultures were obtained from oily sludge after an initial incubation of the oily sludge without any carbon source and then an enrichment transfer with $n$-alkanes $\left(C_{15}-C_{20}\right)$ for acclimation. Activation of alkanes, methane precursor generation and methanogenic pathways are considered as three pivotal stages for the continuous methanogenesis from degradation of alkanes. The presence of functional genes encoding the alkylsuccinate synthase $\alpha$-subunit indicated that fumarate addition is most likely the one of initial activation step for degradation of $n$-alkanes. Degradation intermediates of $n$-alkanes were octadecanoate, hexadecanoate, butyrate, isobutyrate, acetate and propionate, which could provide the appropriate substrates for acetate formation. Both methyl coenzyme M reductase gene and $16 \mathrm{~S}$ rRNA gene analysis showed that microorganisms of Methanoseata were the most dominant methanogens, capable of using acetate as the electron donor to produce methane. Bacterial clone libraries showed organisms of Anaerolineaceae (within the phylum of Chloroflexi) were predominant (45.5\%), indicating syntrophically cooperation with Methanosaeta archaea was likely involved in the process of methanogenic degradation of alkanes. Alkanes may initially be activated via fumarate addition and degraded to fatty acids, then converted to acetate, which was further converted to methane and carbon dioxide by methanogens.
\end{abstract}

Keywords: Alkanes degradation, Anaerolineaceae, Methanosaeta, 165 rRNA gene, Methanogenesis, Microbial community

\section{Introduction}

Methanogenic degradation of alkanes is an important part of microbial enhanced energy recovery (MEER) in which oil in petroleum reservoir may be converted into methane gas. Moreover, it is also an interesting area of research for bioremediation of oil-contaminated environments. Alkanes are quantitatively the most significant

\footnotetext{
*Correspondence: bzmu@ecust.edu.cn

${ }^{1}$ State Key Laboratory of Bioreactor Engineering and Institute of Applied Chemistry, East China University of Science and Technology,

Shanghai, People's Republic of China

Full list of author information is available at the end of the article
}

components of petroleum hydrocarbons (Head et al. 2010). Comparing to other anaerobic degrading conditions, which use nitrate, nitrite, sulphate, chlorate or ferric iron as the electron acceptor, methanogenic degradation of alkanes has the least Gibbs free energy yield. Zengler et al. (1999) firstly reported an enrichment culture that converted long-chain alkanes (specifically hexadecane) to methane under methanogenic conditions. After that, related researches on methanogenic degradation of alkanes have been reported (Anderson and Lovley 2000; Jones et al. 2008; Mbadinga et al. 2012; Gray et al. 2011; Zhou et al. 2012; Wang et al. 2011, 2012; Li et al. 2012; Aitken et al. 2013; Berdugo-Clavijo and Gieg 2014;

\section{Springer}


Embree et al. 2014; Cheng et al. 2013a; Sherry et al. 2014; Abu Laban et al. 2015).

The methanogenic microbial communities capable of degrading petroleum hydrocarbons are complex consortia containing various fermenting bacteria and methanogens. Gray et al. (2010) collected over 3,000 16S rRNA sequences from published data and concluded that the most frequently detected bacteria in hydrocarbon impacted environments include Firmicutes, $\gamma$-proteobacteria, $\delta$-proteobacteria, $\varepsilon$-proteobacteria, $\beta$-proteobacteria, Bacteriodetes, Actinobacter, $\alpha$-proteobacteria, Chloroflexi, Thermotogae, Nitrospira, Spirochaetes, Acidobacter, Planctomycetes and OP11. More recently, Syntrophaceae (Smithella/Syntrophus) were found to directly participate in the degradation of alkanes (Bakermans and Madsen 2002; Kasai et al. 2005; Allen et al. 2007; Ramos-Padron et al. 2011; Gray et al. 2011; Cheng et al. 2013b; Embree et al. 2014; Tan et al. 2014a, b). However, not all alkanes-degrading consortia were detected positive for Syntrophaceae (Smithella/Syntrophus) as the dominant bacteria. Li et al. (2012) showed that Actinobacteria and Nitrospirae were the most abundant bacteria in methanogenic enrichment culture obtained from oilfield production water. An enrichment of microbial community from high-temperature oil field production water contained Firmicutes, Thermodesulfobiaceae, Thermotogaceae, Nitrospiraceae, Dictyoglomaceae, Candidate division OP8 (Mbadinga et al. 2012). A bacterial consortium isolated from petroleum sludge consisting of Pseudomonas, Achromobacter, Bacillus and Micromonospora was also able to degrade $n$-alkanes (Gojgic-Cvijovic et al. 2012). Therefore, other microbes that have the potential of directly degradation of alkanes should not be completely excluded, which is significant for bioremediation in different hydrocarbon contaminated system.

In the present work, we obtained a methanogenic alkanes-degrading enrichment culture with over 1,300 days of incubation as a stable methanogenic alkanes-degrading consortium. We investigated the composition of microbial community and potential functional genes coupling with quantitative PCR analysis. When considering the previous work on enrichment culturing in our laboratory (Wang et al. 2012), the total time of the methanogenic alkanes-degrading enrichment culture was extended for more than 6 years.

\section{Materials and methods}

\section{Enrichment cultures}

In the enrichment culturing process, we transferred about $10 \mathrm{~mL}(20 \%)$ of the inoculum into a $120 \mathrm{~mL}$ autoclaved serum bottle containing $40 \mathrm{~mL}$ of sterilized basal medium, while the bottle was flushed with pure $\mathrm{N}_{2}$ gas after passing through copper filings to remove traces of oxygen. The inocula showing ability of methanogenic degradation of alkanes were taken from the enrichment culture established by Wang et al. (2012). After flushing the serum bottles, they were sealed with butyl rubber stoppers and aluminum crimps (Bellco Glass, Inc., Vineland, NJ, USA).

The basal medium contained $(\mathrm{g} / \mathrm{L}): \mathrm{NaCl}, 0.20$; $\mathrm{MgCl}_{2} \cdot 6 \mathrm{H}_{2} \mathrm{O}, \quad 1.20 ; \mathrm{CaCl}_{2} \cdot 2 \mathrm{H}_{2} \mathrm{O}, 0.10 ; \mathrm{NH}_{4} \mathrm{Cl}, \quad 0.25$; $\mathrm{KH}_{2} \mathrm{PO}_{4}, 0.20 ; \mathrm{KCl}, 1.30 ; \mathrm{NaHCO}_{3}, 2.50$; rezasurin, 0.0001 and $1(\mathrm{~mL} / \mathrm{L})$ of vitamin stock solution and trace element stock solution as described by Wang et al. (2011). $\mathrm{Na}_{2} \mathrm{~S} \cdot 9 \mathrm{H}_{2} \mathrm{O}(0.50 \mathrm{~g} / \mathrm{L})$ was used to reduce medium and the final pH of the basal medium was adjusted to 7.2.

Substrates of a mixture of $n$-alkanes $\left(\mathrm{C}_{15}-\mathrm{C}_{20}\right)$ were supplemented into each $120 \mathrm{~mL}$ serum bottle inoculated with the methanogenic alkanes-degrading enrichment culture (three replications). Composition of $n$-alkanes mixture $\left(C_{15}-C_{20}\right)$ were $n$-pentadecane $(C 15$; $\geq 99 \%), n$-hexadecane (C16; $\geq 99 \%), n$-heptadecane (C17; $\geq 99 \%$ ), $n$-octadecane (C18; $\geq 99 \%), n$-nonadecane (C19; $\geq 99 \%)$ and $n$-eicosane (C20; $\geq 99 \%$ ) (Sigma-Aldrich, Milwaukee, WI, USA). Two sets of control experiments were prepared in the same way as the treatment group: background control group prepared without addition of $n$-alkanes (three replications); autoclaved control group amended with $n$-alkanes but sterilized (three replications).

\section{Chemical analysis}

Gas chromatography (GC) equipped with a $1.5 \mathrm{~m}$ stainless-steel column filled with $5 \AA$ carbon molecular sieves and a flame ionization detector (FID) was used to measure the production of methane in the headspace of each serum bottle over time of incubation. Two hundred microlitre of the gas from the headspace were injected into GC with a micro-syringe. The program setting of the $\mathrm{GC}$ was as follows: the column temperature was $60^{\circ} \mathrm{C}$ for $12 \mathrm{~min}$, and then the temperature increased to $200^{\circ} \mathrm{C}$ at the rate of $15^{\circ} \mathrm{C} / \mathrm{min}$, at the final temperature of $200^{\circ} \mathrm{C}$ maintained for $24 \mathrm{~min}$. The injector, TCD and FID temperatures were set at $200^{\circ} \mathrm{C}$. The standard calibration curves of methane and hydrogen were made based on relationship between peak area and the respective concentrations $\left(\mathrm{R}^{2}=0.994, n=6\right)$.

The residual $n$-alkanes and intermediate metabolites in enrichment cultures of incubation were detected at the end of incubation through GC-MS, an Agilent 6890 GC fitted with a HP-5MS capillary column $(30 \mathrm{~m} \times 0.25 \mathrm{~mm} \times 0.25 \mu \mathrm{m})$ and $5975 \mathrm{MS}$ in full scan mode (Agilent Technologies, Inc.). For detection of residual $n$-alkanes: $50.0 \mu \mathrm{L}$ of cetyl chloride as a surrogate standard was added into the serum bottle, then the culture aliquot was extracted with hexane and dried over anhydrous $\mathrm{Na}_{2} \mathrm{SO}_{4}$. Pooled organic 
layer, transferred to a new vial, and concentrated under a stream of $\mathrm{N}_{2}$. The extracts were injected into GC-MS, program setting was initial oven temperature at $120^{\circ} \mathrm{C}$ for $3 \mathrm{~min}$, and increased at a rate of $8^{\circ} \mathrm{C} /$ min to $260^{\circ} \mathrm{C}$ maintained for $10 \mathrm{~min}$. GC peak area of surrogate standard (cetyl chloride) and alkanes ranging from $\mathrm{C}_{15}$ to $\mathrm{C}_{20}$ were integrated, then obtained the $n$-alkane-to-standard ratio. Finally, the quantity of each $n$-alkane with the peak area ratio was calculated. Intermediate metabolites mainly included long chain fatty acids (LCFAs) and volatile fatty acids (VFAs). Five $\mathrm{mL}$ of culture aliquot of the sample were taken respectively; added with ammonia water to raise $\mathrm{pH}$ to $>12$ and dried in an oven at $110^{\circ} \mathrm{C}$; esterification at $90^{\circ} \mathrm{C}$ for $60 \mathrm{~min}$ by adding $0.5 \mathrm{~mL}$ of $10 \%$ butanol/sulfate solution. Then LCFAs and VFAs were extracted with $0.5 \mathrm{~mL} n$-hexane and $0.5 \mathrm{~mL} n$-dodecane, respectively. The extracts then injected onto the GC-MS. For LCFAs analysis: oven temperature was maintained at $120^{\circ} \mathrm{C}$ for $3 \mathrm{~min}$, increased at a rate of $8^{\circ} \mathrm{C} / \mathrm{min}$ to $260^{\circ} \mathrm{C}$ and maintained for $10 \mathrm{~min}$, and for the VFAs analysis: oven temperature was maintained at $60^{\circ} \mathrm{C}$ for $1 \mathrm{~min}$, increased at a rate of $15^{\circ} \mathrm{C} / \mathrm{min}$ to $130^{\circ} \mathrm{C}$.

\section{DNA extraction and PCR-amplification}

We extracted the total genomic DNA after 1,300 days of incubation. Ten millilitre of active enrichment culture samples were taken from the serum bottles (same bottles as for chemical analysis) and centrifuged at $12,000 \times g$ for $10 \mathrm{~min}$ and the settling materials on the bottom were used for genomic DNA extraction by using a commercial extraction kit (Axygen Biosciences, USA) according to its instructions.

Partial 16S rRNA genes of bacteria and archaea were amplified using the bacterial primer 8F/805R (Savage et al. 2010) and archaeal primer A109F/A915R (Nazina et al. 2006; Weisburg et al. 1991), respectively. PCR conditions for bacterial $16 \mathrm{~S}$ rRNA genes were as follows: $95^{\circ} \mathrm{C}$ for $5 \mathrm{~min}$, followed by 38 cycles of $95^{\circ} \mathrm{C}$ for $30 \mathrm{~s}, 52^{\circ} \mathrm{C}$ for $45 \mathrm{~s}, 72^{\circ} \mathrm{C}$ for $60 \mathrm{~s}$, and a final elongation step at $72^{\circ} \mathrm{C}$ for $10 \mathrm{~min}$. PCR conditions for archaeal 16S rRNA genes were as follows: $95^{\circ} \mathrm{C}$ for $5 \mathrm{~min}$, followed by ten cycles of $95^{\circ} \mathrm{C}$ for $30 \mathrm{~s}, 63^{\circ} \mathrm{C}$ for $30 \mathrm{~s}$ (decreased by $0.5^{\circ} \mathrm{C}$ per cycle to $58^{\circ} \mathrm{C}$ ), $72^{\circ} \mathrm{C}$ for $60 \mathrm{~s}$, after the touchdown 28 additional cycles in which annealing temperature of $58^{\circ} \mathrm{C}$ were performed and a final elongation step at $72^{\circ} \mathrm{C}$ for $10 \mathrm{~min}$.

The alkylsuccinate synthetase genes (ass $A$ ) and methyl coenzyme-M reductase genes $(m c r A)$ were also amplified. The gene assA (alkylsuccinate synthase alphasubunit) encoding alkylsuccinate synthetase (ASS) was considered as a biomarker for detecting fumarate addition pathway in degradation of alkanes (Callaghan et al.
2010). In recent years several researchers have reported the discovery of ass $A$ gene in their methanogenic consortia (Zhou et al. 2012; Mbadinga et al. 2012; Li et al. 2012; Cheng et al. 2013c; Wang et al. 2012; Tan et al. 2013; Kolukirik et al. 2011; Berdugo-Clavijo and Gieg 2014; Tan et al. 2014b; Abu Laban et al. 2015). Methyl coenzyme-M reductase gene $(m c r A)$ is a key gene in the terminal step of methane-producing pathway, the enzyme catalyzes the production of methane by reducing the methyl group bound to coenzyme-M. This gene could be a biomarker in the detection of methanogens (Thauer 1998). The primers of the functional genes used in this study are given in Additional file 1: Table S1. PCR conditions were as follows: $95^{\circ} \mathrm{C}$ for $5 \mathrm{~min}$, followed by 10 cycles of $95^{\circ} \mathrm{C}$ for $30 \mathrm{~s}, 60^{\circ} \mathrm{C}$ for $30 \mathrm{~s}$ (decreased by $0.5^{\circ} \mathrm{C}$ per cycle to $55^{\circ} \mathrm{C}$ ), $72^{\circ} \mathrm{C}$ for $60 \mathrm{~s}$, after the touchdown 30 additional cycles in which annealing temperature of $55^{\circ} \mathrm{C}$ were performed and a final elongation step at $72^{\circ} \mathrm{C}$ for $10 \mathrm{~min}$.

\section{Construction of $16 \mathrm{~S}$ rRNA genes and ass A, mcrA functional genes libraries}

The PCR-amplified and then purified bacterial and archaeal 16S rRNA and assA, mcrA, functional gene fragments were cloned into $E$. coli using pMD19-T simple vector kit (TaKaRa Bio Inc., Japan) according to the manufacturer instructions. White clones were picked randomly and inoculated into $1 \mathrm{~mL}$ of Luria Broth (LB) medium containing ampicillin and incubated at $37^{\circ} \mathrm{C}$ for $24 \mathrm{~h}$. Primer set M13-47 (5'-CGCCAGGGTTTTCC CAGTCACGAC-3') and RV-M (5'-GAGCGGATA ACAATTTCACACAGG-3') was used to determine the positive clones. Sequencing of the positive clones was performed on an ABI 377 automated sequencer. Sequences of the respective clone libraries were trimmed to remove vector and primer sequences using MEGA6.0 software (Tamura et al. 2013). Chimeric sequences of $16 \mathrm{~S}$ rRNA gene were checked and removed by Bellerophon (Huber et al. 2004). Operational taxonomic units (OTUs) were classified using FastGroupII (Yu et al. 2006) with the $97 \%$ similarity. The OTUs of ass A, mcrA functional genes were translated using ExPASY translation tool (http://web.expasy.org/translate/). Gene sequences of 16S rRNA and the protein sequences of functional genes were compared to the GenBank Database using BLAST to match the most similar sequences. Phylogenetic and molecular evolutionary analyses were conducted using MEGA6.0 software (Tamura et al. 2013) with neighborjoining method (Saitou and Nei 1987) and 1,000 bootstrap replicates.

The 16S rRNA gene sequences and ass A, morA functional gene sequences from the clone libraries were 
deposited in GenBank with the accession numbers KJ432869 to KJ432905 and KJ461623 to KJ461653.

\section{$16 \mathrm{~S}$ rRNA and functional genes quantitative PCR assay}

The copies of 16S rRNA genes of Archaea, Bacteria, Methanosarcinaceae, Methanosaetaceae and functional genes of ass A, mcrA were quantified by using SYBR Green I Real-Time PCR (BioRad CFX96 thermocycler, Bio-Rad Laboratories Inc., USA). A ten-fold dilution series of plasmids containing target DNA sequences were chosen as a calibration standard for establishing the standard curve. The primers used in the quantitative PCR are shown in Additional file 1: Table S1. Twenty $\mu \mathrm{L}$ volume of quantitative PCR reactions comprised SYBR Green Realtime PCR Master Mix-Plus (10 $\mu \mathrm{L}$ ) (TaKaRa Bio Inc., Japan), Plus Solution $2 \mu \mathrm{L}$ (TaKaRa Bio Inc., Japan), PCR primers (1 $\mu \mathrm{L}$ of each), sterile water $(4 \mu \mathrm{L})$, DNA sample $(2 \mu \mathrm{L})$. The q-PCR conditions were predenaturation at $95^{\circ} \mathrm{C}$ for $3 \mathrm{~min}$, followed by 38 cycles of denaturation at $94^{\circ} \mathrm{C}$ for $20 \mathrm{~s}$, annealing at specific primer temperature (Additional file 1: Table S1) for $30 \mathrm{~s}$, elongation at $72^{\circ} \mathrm{C}$ for $60 \mathrm{~s}$.

\section{Results}

The residual $\boldsymbol{n}$-alkanes, intermediate metabolites and headspace methane generation

In this study, the methanogenic enrichment culture amended with $n$-alkanes had a lag phase of 157 days, after that it began to produce detectable methane and accumulated to a total of $109.2 \mu \mathrm{mol}$ of methane after 1,323 days. The control group without any carbon source generated $3.9 \mu \mathrm{mol}$ of methane after 1,323 days of incubation as background level (Figure 1). We have successfully detected the residual $n$-alkanes and intermediate metabolites (LCFAs and VFAs), after more than 1,300 days of incubation under methanogenic conditions. The consumption of $n$-alkanes in active enrichment cultures was obtained by subtracting the substrates remained in the autoclaved controls by the residuals in the active enrichment cultures. The net loss of total $n$-alkanes was $19.85 \mu \mathrm{mol}$, by assuming all the consumed $n$-alkanes were used for producing methane, the predicted methane produced should reach $276.03 \mu \mathrm{mol}$ (Symons and Buswell 1933; Zengler et al. 1999). Considering the detected methane of $109.2 \mu \mathrm{mol}$, methane accumulated in headspace accounted for $39.56 \%$ of theoretically predicted value. Intermediate metabolites were octadecanoate, hexadecanoate, butyrate, isobutyrate, acetate and propionate.

\section{Phylogenetic analyses of bacteria}

For the phylogenetic analysis of bacteria, more than 100 clones were picked and sequenced. In total 77 valid

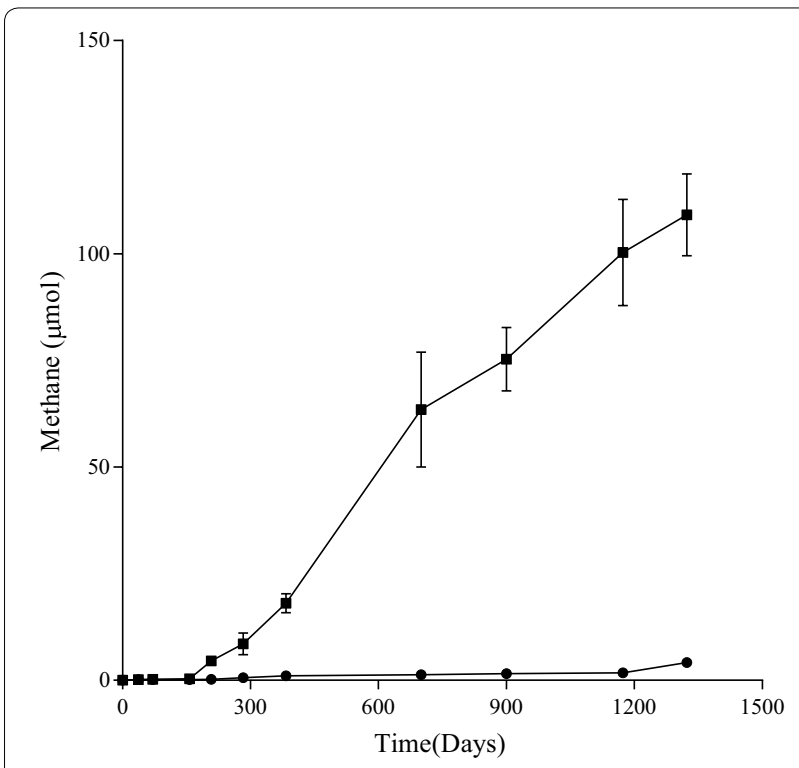

Figure 1 Methane production of the $n$-alkanes degradation consortium under methanogenic conditions. The curve with (filled square) means incubated with $n$-alkanes mixture $\left(\mathrm{C}_{15}-\mathrm{C}_{20}\right)$ as the sole carbon and energy source (three replications) and (filled circle) means without any $n$-alkanes and other carbon sources as the control group (three replications).

sequences after removing the vector and chimeric sequences were obtained. These 77 valid sequences were analyzed and classified into 20 OTUs by FastGroupII with the 97\% similarity (Figure 2). The OTU (AD-Bacteria-59) contains the most sequences (34 out of 77 valid sequences followed by OTU (AD-Bacteria-84) with 11 sequences. OTU (AD-Bacteria-59) belongs to Anaerolineae within the phylum Chloroflexi and OTU (AD-Bacteria-84) belongs to Spirochaetae. Phylogenetic analysis reveals that these 20 OTUs affiliated with $\beta-, \gamma-, \delta$-Proteobacteria, Spirochaetae, Deferribacteres, Chlorobi and Chloroflexi (Figure 2). Among these bacteria, Chloroflexi have the highest number of clones (46.7\%), followed by Spirochaetae $(21.0 \%)$, and the remaining of $32.3 \%$ belongs to the phylum of Proteobacteria, Deferribacteres, Chlorobi, Acetothermia and Unclassified Bacteria. Sequences with high similarity from oil or hydrocarbon-impacted environments are highlighted in bold and black (Figure 2).

\section{Phylogenetic analyses of Archaea based on 16S rRNA and $\boldsymbol{m}$ crA genes}

In total 49 valid sequences were obtained from 60 archaeal clones after vector and chimeric checking, resulting in 17 OTUs by FastGroupII with the 97\% similarity (Figure 3a). All of the 17 OTUs belong to Methanosarcinales, in which Methanosaeta accounts for $98 \%$ and Methanosarcina only accounts for the remaining $2 \%$. 


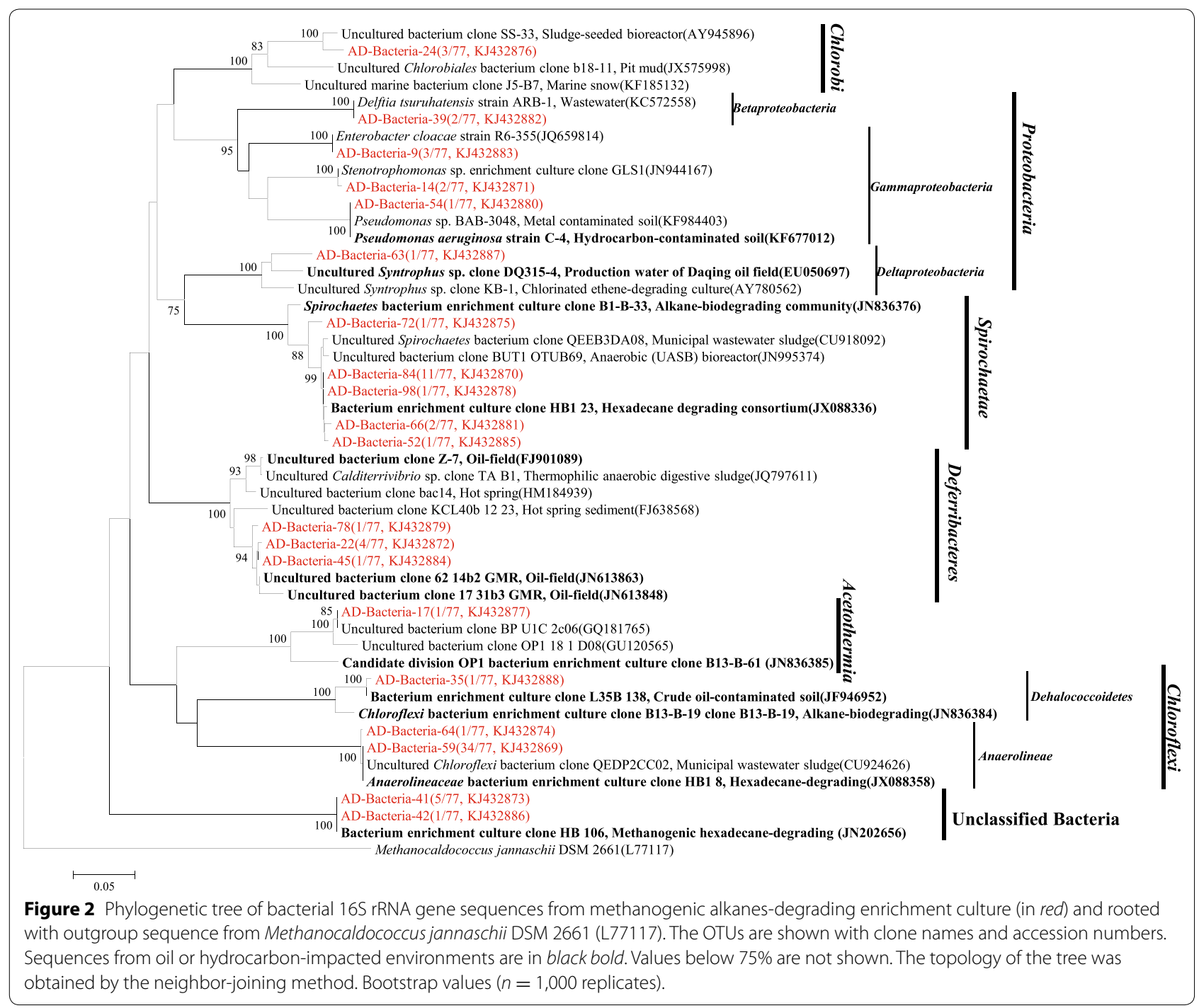

Obviously, Methanosaeta was the dominant archaea by 16S rRNA gene clone libraries analysis. Sequences with high similarity from oil or hydrocarbon-impacted environments are highlighted in bold and black (Figure 3a).

For $m c r A$ genes clone library analysis, 50 clones were picked randomly for sequencing and resulted ten OTUs by FastGroupII with the $97 \%$ similarity (Figure 3b). OTU of AD-mcrA-48 contains the most clones. A $72.0 \%$ of the clones belongs to the order of Methanosarcinales which covers the genus of Methanosaeta (64\%) and Methanosarcina (8\%), and the remaining $28.0 \%$ clones belongs to the order of Methanomicrobiales which was not detected in the archaeal 16S rRNA gene clone library.

\section{Phylogenetic analysis of ass A functional gene}

The primer set assA2F/assA2R was chosen for PCR amplification (Additional file 1: Table S1). In total 48 sequences were analyzed through FastGroupII with the 97\% similarity and only one OTU was found (Figure 4). Phylogenetic analysis of the deduced amino acid revealed that this OTU was $90 \%$ similar to gene sequence (AET09978) from Shengli oil field (Cheng et al. 2013c) and closely related to the strain Smithella sp. The primer set $1432 \mathrm{~F}$ and ass/bssR (Callaghan et al. 2010) used by Wang et al. (2012) did not generate any positive products.

\section{Quantitative PCR}

The quantitative PCR of 16S rRNA genes of Archaea, Bacteria, Methanosarcinaceae, Methanosaetaceae and functional genes ass $A$, mcr $A$ from methanogenic alkanesdegrading enrichment culture consortia were performed in BioRad CFX96 thermocycler. In the q-PCR reactions the efficiency was between 93.1 and $120 \%, R^{2}$ values were above 0.958 (triplicate samples). The log gene copies 


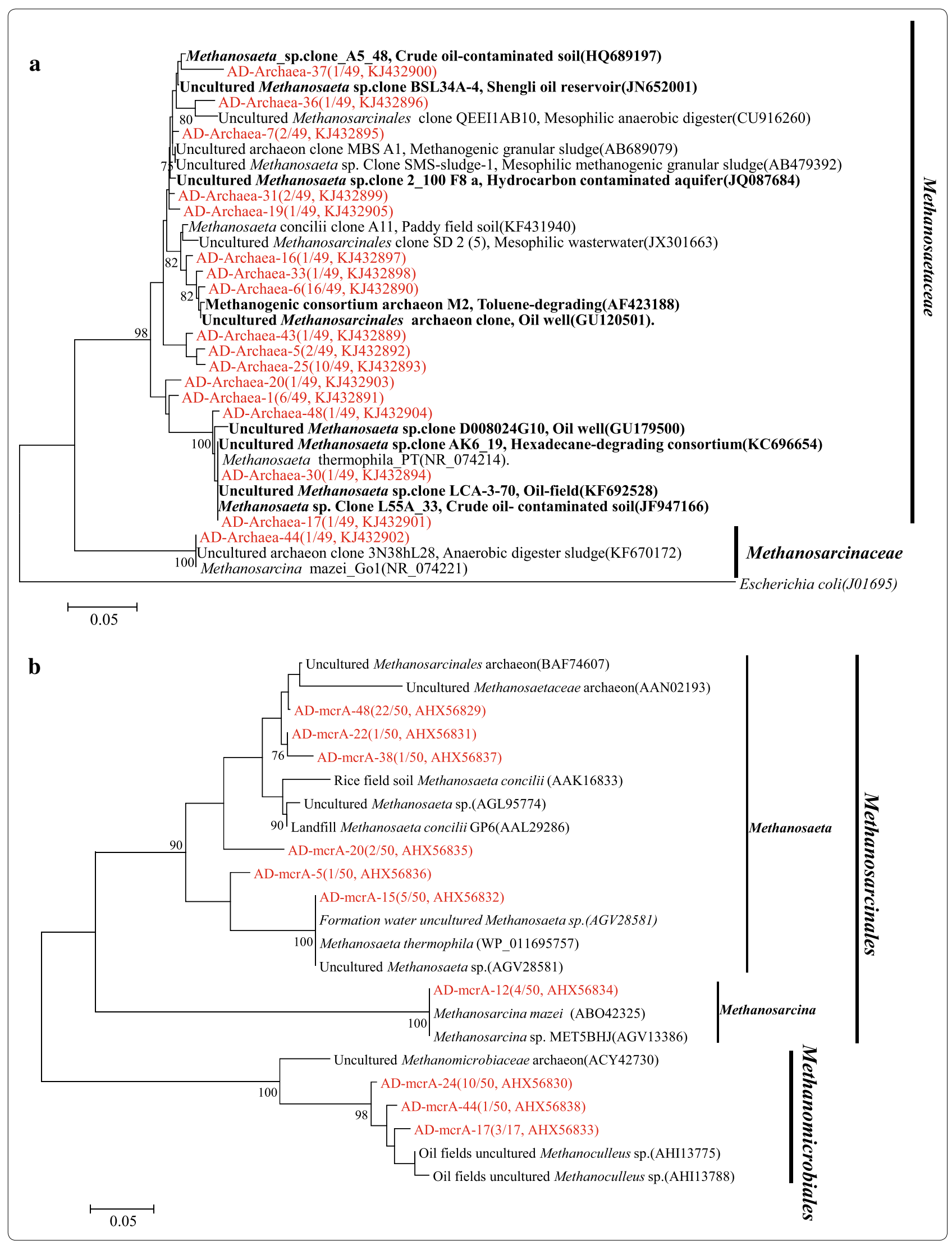


(see Figure in previous page)

Figure 3 Phylogenetic tree of archaeal 16S rRNA gene sequences from methanogenic alkanes-degrading enrichment culture (in red) and rooted with outgroup sequence from Escherichia coli (J01695). The OTUs are shown with clone names and accession numbers. Sequences from oil or hydrocarbon-impacted environments are in black bold. The topology of the tree was obtained by the neighbor-joining method. Bootstrap values ( $n=1,000$ replicates), the values below $75 \%$ are not shown (a); phylogenetic tree of deduced amino acid sequences of methyl coenzyme-M reductase genes ( $\mathrm{mcr} A$ ) from methanogenic alkanes-degrading enrichment culture (in red). Topology of the tree was obtained by the neighbor-joining method. The evolutionary distances were computed using the Poisson correction method. Bootstrap values ( $n=1,000$ replicates), values below $75 \%$ are not shown $(\mathbf{b})$.

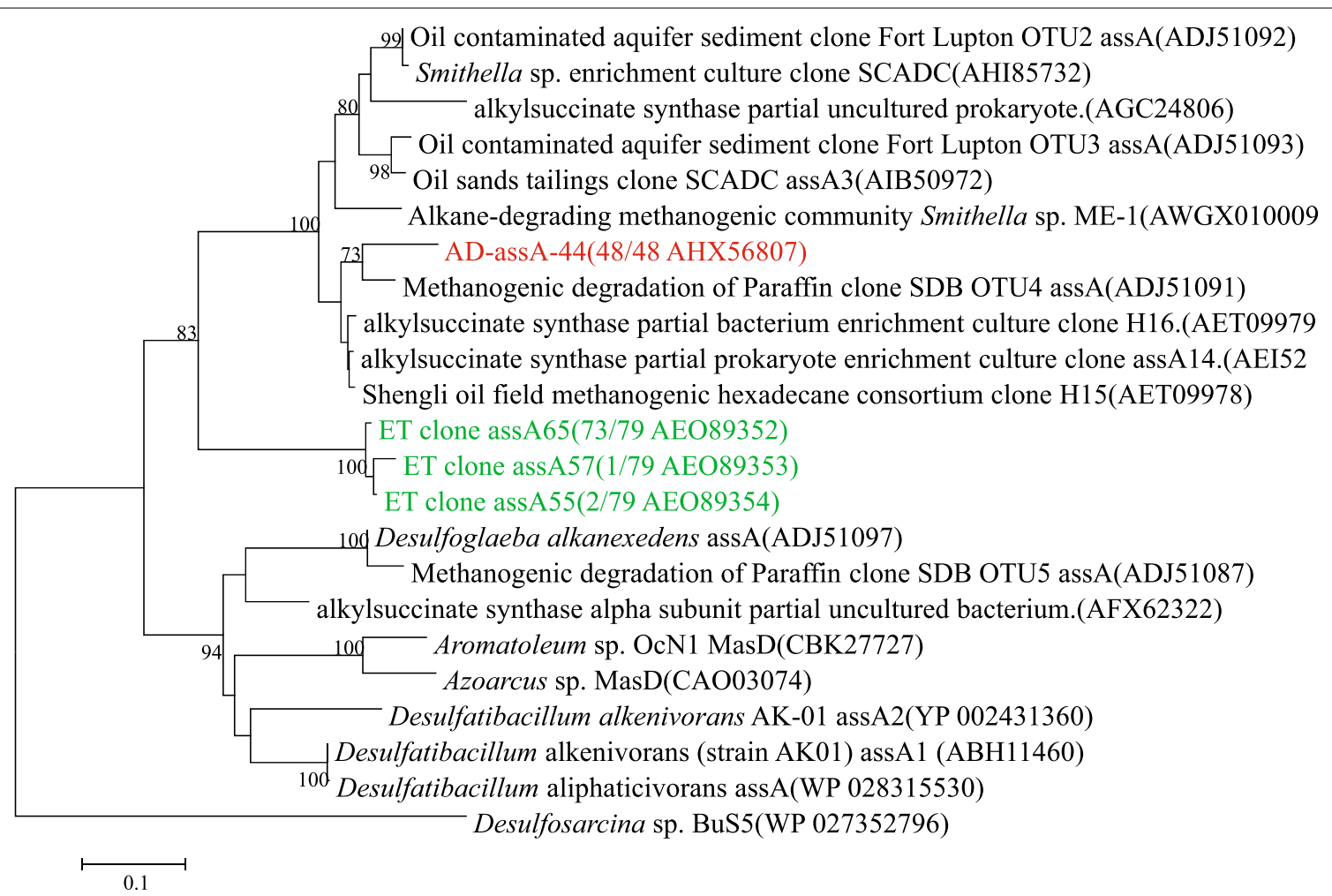

Figure 4 Phylogenetic tree of deduced amino acid sequences of alkylsuccinate synthetase genes (assA) genes from methanogenic alkanesdegrading enrichment culture (in red). Clone sequences with green were detected in the stage III by Wang et al. (2012). The topology of the tree was obtained by the maximum likelihood method. Bootstrap values ( $n=1,000$ replicates), values below $70 \%$ are not shown.

of Archaea, Bacteria, Methanosarcinaceae, Methanosaetaceae, ass $A$ and $m c r A$ per milliliter of culture aliquot were $7.62 \pm 0.38,6.36 \pm 0.084,4.85 \pm 0.05,6.43 \pm 0.33$, $3.93 \pm 0.03$ and $5.20 \pm 0.09$, respectively.

\section{Discussion}

The microbial community of anaerobic methanogenic degradation of alkanes has been incubated for over 6 years in four stages: original oily sludge sample from Shanghai Oil Refinery (Stage I); initial enrichment culture of oily sludge sample without any additional organic carbon source incubated for more than 500 days (Stage II); the first methanogenic enrichment transfer incubation from "Stage II" amended with $n$-alkanes as the sole carbon source incubated for another 500 days (Stage III); the second enrichment transfer incubation from "Stage III" incubated for over 1,300 days (Stage IV). Investigation of stage I, II, III had been accomplished previously by Wang et al. (2012), the stage IV was conducted in the present research. A total of $109.2 \mu \mathrm{mol}$ of methane were detected after 1,300 days of incubation, and the gas reached nearly $50 \mu \mathrm{mol}$ after 500 days, this was more than recorded previously in the first transfer of culture after 500 days $(18 \mu \mathrm{mol})$. Obviously, a more stable and efficient consortium for methanogenesis from alkane in the second enrichment transfer culture was obtained. The residual $n$-alkanes and presence of the intermediates including octadecanoate, hexadecanoate, butyrate, isobutyrate, acetate and propionate, suggested that the 
methanogenic alkanes-degrading process is still active in process.

\section{Anaerolineaceae turned to be the dominant bacteria after long-term incubation under alkanes-dependent methanogenic conditions}

Bacterial community varied over the time of incubation (Figure 5a). The most obvious change in the bacterial community was that the phylum of Chloroflexi (vast majority of the family Anaerolineaceae) became the most dominant bacteria after 6 years of incubation. Comparing to the first and second transfer incubation (Stage III and Stage IV), the dominant consortium of bacteria had shifted from $\delta$-Proteobacteria $(38.5 \%)$ and Firmicutes (30.8\%) to the phylum of Chloroflexi (46.7\%) and Spirochaetae (21.0\%). The clones affiliated with
$\delta$-Proteobacteria decreased to $1.3 \%$ while Firmicutes clones were not detectable any more. After 500 days of the initial enrichment culture, relative abundance of Chloroflexi remains steady from $28.4 \%$ (Stage I) to $23.2 \%$ (Stage II). In Stage III after first transfer incubation, abundance of Chloroflexi dropped gently to $15.4 \%$. For this slight drop in Stage III, when $n$-alkanes were amended as the sole carbon source, Chloroflexi might face a situation where some growth factors may be depleted leading to a longer lag phase for Chloroflexi. After the second transfer incubation of 1,300 days (Stage IV) when acclimated into the environmental conditions, Chloroflexi increased sharply from the initial amount of $15.4-46.7 \%$.

Numerous studies have demonstrated that Syntrophaceae (Smithella/Syntrophus) play a key role in hydrocarbon contained system and are responsible for
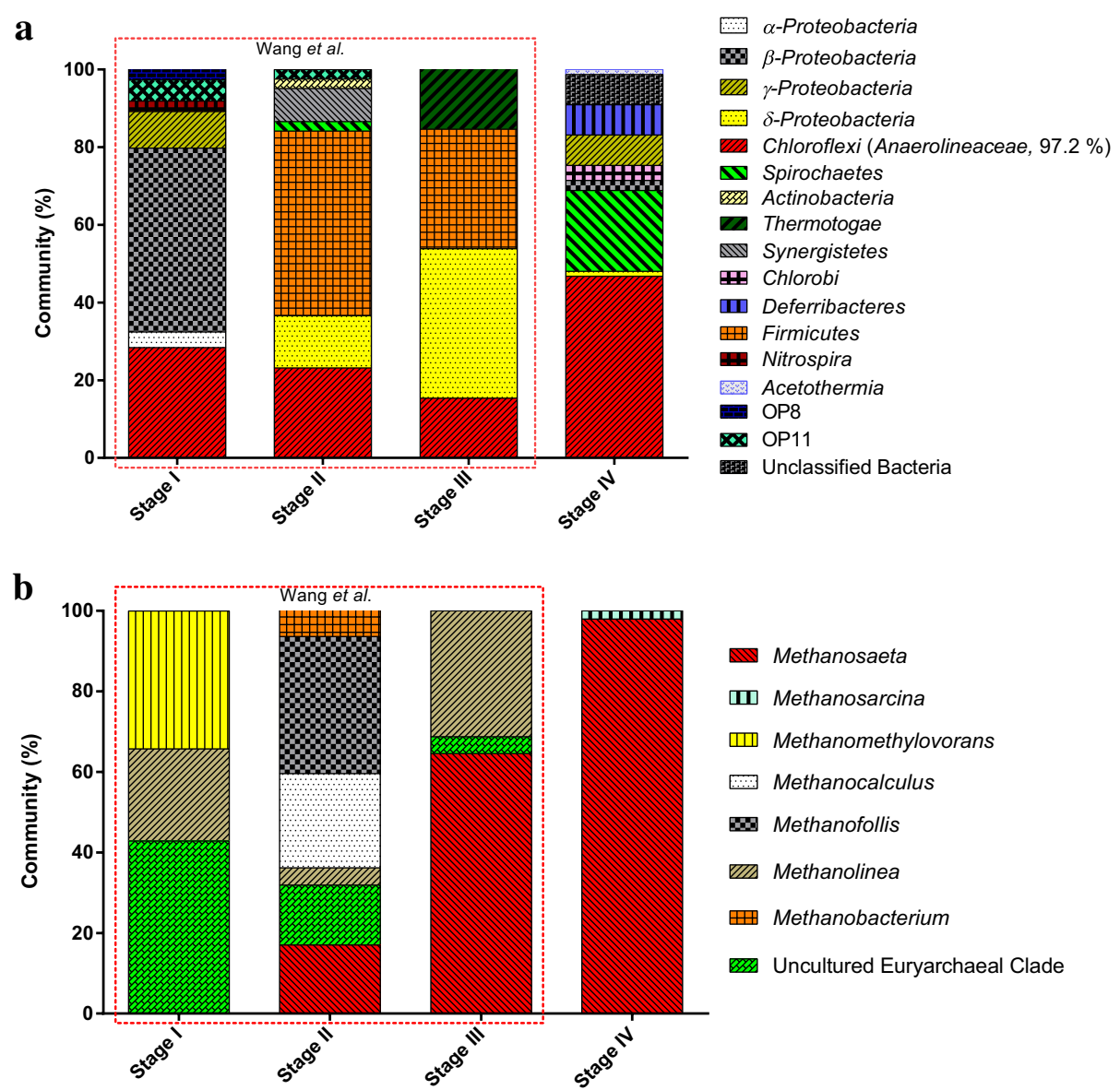

Figure 5 The microbial community varied with the time of incubation from the analysis of bacteria and archaea 165 rRNA gene clone libraries. Relative proportion of bacteria lineages (a) and archaea lineages $(\mathbf{b})$ in the four stages during the methanogenic alkanes-degrading enrichment culture. "Stage I" represents the original oily sludge sample from Shanghai Oil Refinery; "Stage II" represents the initial enrichment culture of oily sludge sample without any additional carbon source and incubated for more than 500 days; "Stage III" represents methanogenic enrichment transfer incubation from "Stage II" amended with $n$-alkanes as the sole carbon source for another 500 days, for details see Wang et al. (2012). "Stage IV" represents the second transfer incubation from "Stage III" for over 1,300 days. 
alkane activation and LCFA oxidation (Bakermans and Madsen 2002; Kasai et al. 2005; Allen et al. 2007; RamosPadron et al. 2011; Gray et al. 2011; Cheng et al. 2013a; Embree et al. 2014; Tan et al. 2014a, b; Zengler et al. 1999). Whereas, only one sequence (KJ432887) affiliated with Syntrophaceae, accounts for $1.3 \%$ of the total bacterial sequences, was detected in our consortium. Interestingly, Anaerolineaceae turned to be the most predominant bacteria (nearly a half), which means not only Syntrophus or Smithella-like bacteria can contribute for the methanogenic degradation of alkanes, Anaerolineaceae are also worth to be concerned. Anaerolineaceae comprise obligate anaerobes, as a majority in our alkanes-degrading consortium is not a surprise, they have occurred in many oil and hydrocarbon environments. In order to illustrate that Anaerolineaceae played an important role in hydrocarbon degradation, a survey of Anaerolineaceae associated with oil and hydrocarbon environment are summarized in Table 1. Ficker et al. (1999) firstly reported that Chloroflexi was related to toluene degradation in a 10-years period toluene-degrading methanogenic consortium. Sutton et al. (2013) found that Anaerolineaceae may be associated with the anaerobic degradation of oil-related compounds, this bacterial lineage was also reported as the most frequently encountered bacteria taxon in anaerobic $n$-alkane degradation (Sherry et al. 2013). Savage et al. (2010) detected that Anaerolineaceae as one of the community members in metabolism of low-molecular-weight alkanes ( $n$-propane and $n$-pentane) under mesophilic sulfate-reducing conditions, which showed the potential of hydrocarbon degradation for these lineage organisms. Several researchers found that the class of Anaerolineae has the traits of filamentous morphology, heterotrophic and low growth rate in anaerobic condition (Sekiguchi et al. 2001). The formation of sludge granules by Anaerolineae was commonly detected and considered important for the settleability in upflow anaerobic sludge blanket system (Yamada and Sekiguchi 2009). This filamentous morphology may facilitate the degradation of hydrocarbons by Anaerolineaceae in cooperation with other microorganisms. Because filamentous morphology is conducive to the granulation (Guiot et al. 1992; Yamada et al. 2005), an effective way for aggregation of microbes and substrates. Community genomic analyses indicated that most members in the phylum of Chloroflexi are anaerobic acetogenic microbes, which also have the genomes of complete Wood-Ljungdahl pathway and $\beta$-oxidation of saturated fatty acids (Hug et al. 2013). Thus, we can infer that Chloroflexi (more specifically, Anaerolineaceae) have the ability of providing organic acid (such as acetate) to other microorganisms like acetoclastic methanogens.
Since the Spirochaetae was the predominant bacteria after Chloroflexi, it must play an important role during the degradation of alkanes. Some researchers had shown Spirochaeta as a participator in hydrocarbon degradation (Paissé et al. 2008; Berdugo-Clavijo et al. 2012; HirschlerRéa et al. 2012; Kobayashi et al. 2012), besides, a mesophilic strictly anaerobic strain Spirochaetas maragdinae sp. has been isolated from oil field (Magot et al. 1997). Although Deferribacteres was detected at a low level (7.8\%), it should not be ignored. Deferribacter thermophilus, which could utilize complex organic compounds and small molecules substrates like hydrogen and acetate as electron donors, has been isolated from a submarine oil reservoir (Greene et al. 1997). This kind of microorganism was also detected in methanogenic enrichment culture from oil reservoir in our laboratory before (Wang et al. 2011).

\section{Methanosaeta turned to be the dominant Archaea after long-term incubation under alkanes-dependent methanogenic conditions}

After additional 1,300 days of incubation amended with $n$-alkanes, Methanosaeta were still the dominant organisms, and the proportion increased from 64.6 to $98.0 \%$ (Figure 5b). 16S rRNA gene clone libraries showed that Methanosaeta was 50 times more than Methanosarcina, which was consistent with q-PCR data $\mathrm{f}$ (log gene copies was $6.43 \pm 0.33$ and $4.85 \pm 0.05$, respectively). Both Methanosaetaceae and Methanosarcinaceae were acetoclastic methanogens which take part in converting acetate into methane and carbon dioxide directly (Ferry 1993), Methanosarcinaceae could also generate methane by utilizing methyl, hydrogen, carbon dioxide and formic acid. Detection of mcrA functional gene suggests Methanosaeta (64\%) was still the dominant organism. mcrA gene affiliated with Methanomicrobiales was detected but not in 16S rRNA gene clone library. This may be due to the too little of Methanomicrobiales in the system. In addition to that, since the acetogens of Anaerolineaceae detected as the most dominant bacteria, plenty of acetate should have generated during the intermediate metabolites. However, the acetate was detected in trace amount. Methanosaeta could have consumed acetate once it was generated and this may lead to the minimal residual of acetate. All of the evidence presented above shows that aceticlastic methanogenesis becomes the most predominant methanogenic pathway.

\section{Possible metabolic pathway of methanogenic alkane's degradation}

For the initial activation of alkanes, three mechanisms are considered to be involved, they are subterminal addition to fumarate, intra-hydroxylation and anaerobic 
Table 1 A survey of oil and hydrocarbon associated Anaerolineaceae

\begin{tabular}{|c|c|c|c|c|c|}
\hline References & Accession number & Clone/strain & Isolation source & Region & Percentage $^{a}$ \\
\hline This study & KJ432869 & AD_Bacteria_59 & $\begin{array}{l}\text { Methanogenic } n \text {-alkanes-degrading consortium from } \\
\text { oily sludge enrichment cultures for over 1,300 days }\end{array}$ & China & 100 \\
\hline \multirow[t]{2}{*}{ Sun and Cupples (2012) } & JN806351 & DSS-20 & Toluene-degrading microbial communities & USA & 100 \\
\hline & JN806343 & DSS-12 & Toluene-degrading microbial communities & USA & 99 \\
\hline Yan et al. (2006) & DQ080186 & B45 & $\begin{array}{l}\text { The reductive dechlorination of 2,3,4,5-tetrachlorobi- } \\
\text { phenyl in three different sediment cultures }\end{array}$ & USA & 96 \\
\hline \multirow[t]{2}{*}{ Winderl et al. (2008) } & EU266919 & D25_46 & $\begin{array}{l}\text { Toluene degraders in tar-oil contaminated aquifer sedi- } \\
\text { ments }\end{array}$ & Germany & 96 \\
\hline & EU266901 & D25_25 & $\begin{array}{l}\text { Toluene degraders in tar-oil contaminated aquifer sedi- } \\
\text { ments }\end{array}$ & Germany & 96 \\
\hline Tischer et al. (2013) & JQ087241 & Clone 1_76_3_b & $\begin{array}{l}\text { Push core sediment sample from the vadose zone of a } \\
\text { hydrocarbon contaminated aquifer }\end{array}$ & Germany & 95 \\
\hline Li et al. (Genbank) & KJ730067 & Clone B199 & Biogas digester sediment & China & 94 \\
\hline \multirow[t]{2}{*}{ Sherry et al. (2013) } & JQ033882 & SRO176E01 & $\begin{array}{l}\text { Anaerobic biodegradation of crude oil under sulphate- } \\
\text { reducing conditions in } 176 \text { days incubation period }\end{array}$ & UK & 93 \\
\hline & JQ033889 & SRO302B05 & $\begin{array}{l}\text { Anaerobic biodegradation of crude oil under sulphate- } \\
\text { reducing conditions in } 302 \text { days incubation period }\end{array}$ & UK & 93 \\
\hline Lienen et al. $(\text { Genbank) })^{b}$ & KF147579 & Clone 7932270 & Mesophilic anaerobic digester in full-scale biogas plant & Germany & 93 \\
\hline Gieg et al. (2008) & EU037975 & $\lg 1 \mathrm{e} 04$ & $\begin{array}{l}\text { Bioenergy production via microbial conversion of } \\
\text { residual oil to natural gas }\end{array}$ & USA & 93 \\
\hline Dojka et al. (1998) & AF050570 & WCHB1-57 & $\begin{array}{l}\text { Hydrocarbon and chlorinated-solvent-contaminated } \\
\text { aquifer }\end{array}$ & USA & 93 \\
\hline Gray et al. (2011) & GU996561 & MO302A7 & $\begin{array}{l}\text { Crude oil degrading methanogenic microcosms, } \\
302 \text { days }\end{array}$ & UK & 92 \\
\hline Gieg et al. (2008) & EU037963 & E449-5 & $\begin{array}{l}\text { Bioenergy production via microbial conversion of } \\
\text { residual oil to natural gas }\end{array}$ & USA & 91 \\
\hline Gray et al. (2011) & GU996562 & MO302C11 & $\begin{array}{l}\text { Crude oil degrading methanogenic microcosms, } \\
302 \text { days }\end{array}$ & UK & 91 \\
\hline Penner et al. $(G e n b a n k)^{b}$ & EU522649 & Ctrl1-8D & $\begin{array}{l}\text { Hydrocarbon-degrading methanogenic microbial } \\
\text { consortia from oil sands tailings }\end{array}$ & Canada & 91 \\
\hline Lv et al. (Genbank) & KJ468504 & Clone B16-24 & Palmitate degradation microcosm in oil field & China & 90 \\
\hline \multirow[t]{2}{*}{ Yamada et al. (2007) } & NR041354 & GOMI-1 & $\begin{array}{l}\text { Methanogenic propionate-degrading consortia in } \\
\text { thermophilic digester sludge }\end{array}$ & Japan & 90 \\
\hline & NR041355 & Strain KOME-1 & $\begin{array}{l}\text { Methanogenic propionate-degrading consortia in } \\
\text { thermophilic digester sludge }\end{array}$ & Japan & 90 \\
\hline Dojka et al. (1998) & AF050569 & WCHB1-31 & $\begin{array}{l}\text { Hydrocarbon and chlorinated-solvent-contaminated } \\
\text { aquifer }\end{array}$ & USA & 90 \\
\hline Allen et al. (2007) & DQ663957 & $5 C 38$ & Petroleum-contaminated sediments & USA & 90 \\
\hline \multirow[t]{2}{*}{ Abu Laban et al. (2015) } & KJ635758 & IsoM-30 & $\begin{array}{l}\text { Biodegradation of } C_{7} \text { and } C_{8} \text { iso-alkanes under metha- } \\
\text { nogenic conditions }\end{array}$ & Canada & 90 \\
\hline & KJ635796 & IsoM-108 & $\begin{array}{l}\text { Biodegradation of } C_{7} \text { and } C_{8} \text { iso-alkanes under metha- } \\
\text { nogenic conditions }\end{array}$ & Canada & 90 \\
\hline Herrmann et al. (2008) & EF417532 & BAC19-1 & $\begin{array}{l}\text { In situ microcosms in a monitoring well of an anoxic } \\
\text { benzene-contaminated aquifer }\end{array}$ & Germany & 89 \\
\hline Schlötelburg et al. (2000) & AJ249111 & SHA-53 & $\begin{array}{l}\text { Bacteria of an anaerobic 1,2-dichloropropane-dechlorin- } \\
\text { ating mixed culture }\end{array}$ & Germany & 89 \\
\hline \multirow[t]{2}{*}{ Winderl et al. (2008) } & EU266859 & D15_19 & $\begin{array}{l}\text { Toluene degraders in tar-oil contaminated aquifer sedi- } \\
\text { ments }\end{array}$ & Germany & 89 \\
\hline & EU266865 & D15_26 & $\begin{array}{l}\text { Toluene degraders in tar-oil contaminated aquifer sedi- } \\
\text { ments }\end{array}$ & Germany & 88 \\
\hline Abu Laban et al. (2015) & KJ635769 & IsoM-41 & $\begin{array}{l}\text { Biodegradation of } C_{7} \text { and } C_{8} \text { iso-alkanes under metha- } \\
\text { nogenic conditions }\end{array}$ & Canada & 88 \\
\hline Kuppardt et al. (Genbank) ${ }^{b}$ & KF443371 & Zz9-00_C6 & Toluene-degrading consortia & Germany & 87 \\
\hline Savage et al. (2010) & GU211123 & ZodOTU50-C07 & $\begin{array}{l}\text { Biodegradation of low-molecular-weight alkanes under } \\
\text { mesophilic, sulfate-reducing conditions }\end{array}$ & USA & 87 \\
\hline
\end{tabular}


Table 1 continued

\begin{tabular}{|c|c|c|c|c|c|}
\hline References & Accession number & Clone/strain & Isolation source & Region & Percentage $^{a}$ \\
\hline Riviere et al. (2009) & CU922908 & QEDR2BG03 & $\begin{array}{l}\text { Mesophilic anaerobic digester which treats municipal } \\
\text { wastewater sludge }\end{array}$ & France & 87 \\
\hline Fang (Genbank) ${ }^{b}$ & JQ772434 & 420DB-7 & $\begin{array}{l}\text { High-temperature oil field production fluids incubated } \\
\text { for } 420 \text { days }\end{array}$ & China & 86 \\
\hline \multirow[t]{2}{*}{ Cheng and Lu (Genbank) ${ }^{\mathrm{b}}$} & JX088360 & HB1_18 & $\begin{array}{l}\text { Methanogenic hexadecane-degrading consortium } \\
\text { at different incubation temperatures enriched with } \\
\text { crude oil-contaminated soil }\end{array}$ & China & 86 \\
\hline & JX088361 & LB1_11 & $\begin{array}{l}\text { Methanogenic hexadecane-degrading consortium } \\
\text { at different incubation temperatures enriched with } \\
\text { crude oil-contaminated soil }\end{array}$ & China & 86 \\
\hline Savage et al. (2010) & GU211124 & ZodOTU21-C08 & $\begin{array}{l}\text { Biodegradation of low-molecular-weight alkanes under } \\
\text { mesophilic sulfate-reducing conditions }\end{array}$ & USA & 85 \\
\hline \multirow[t]{2}{*}{ Cheng and Lu (Genbank) ${ }^{b}$} & JF946983 & Clone L35B_120 & $\begin{array}{l}\text { Methanogenic hexadecane-degrading consortium } \\
\text { at different incubation temperatures enriched with } \\
\text { crude oil-contaminated soil }\end{array}$ & China & 84 \\
\hline & JF946983 & Clone L35B_120 & $\begin{array}{l}\text { Methanogenic hexadecane-degrading consortium } \\
\text { at different incubation temperatures enriched with } \\
\text { crude oil-contaminated soil }\end{array}$ & China & 84 \\
\hline Wang et al. (Genbank)b & JN038290 & EK_Ca689 & Petroleum-contaminated soil & China & 81 \\
\hline Ficker et al. (1999) & AF423186 & Eub-6 & Toluene-degrading methanogenic consortium & Canada & 81 \\
\hline Winderl et al. (2008) & EU266855 & D15_15 & $\begin{array}{l}\text { Toluene degraders in tar-oil contaminated aquifer sedi- } \\
\text { ments }\end{array}$ & Germany & 80 \\
\hline Militon et al. (2010) & AM935699 & $\mathrm{AMCH} 2$ & $\begin{array}{l}\text { Pilot-scale bioremediation process of a hydrocarbon- } \\
\text { contaminated soil }\end{array}$ & France & 77 \\
\hline
\end{tabular}

Family level assignment based on RDP taxonomic classification.

a Sequence identity with KJ432869 (this study) determined by BLAST.

b Unpublished.

hydroxylation followed by carboxylation (Callaghan 2013). Among them, fumarate addition is the most prevalent and best characterized mechanism in anaerobic hydrocarbon degradation at present (Aitken et al. 2013). The presence of ass $A$ functional gene suggests that fumarate addition may be involved in the initial activation of alkanes in this methanogenic alkanes-degrading culture but alternative activation mechanisms still cannot be excluded. Assuming that the assA gene detected in our methanogenic culture are from members of the Proteobacteria and since the Proteobacteria represented about $11.7 \%$ of the bacterial sequences analyzed, our assumption is consistent with the low copy number of the ass $A$ gene in the culture. On the other hand, it is possible and even likely that the genes originated from other organisms within the consortium. However, this remains to be elucidated.

This methanogenic alkanes-degrading enrichment culture contains a complicated consortium including bacteria and archaea, which utilize $n$-alkanes as the sole carbon source. Anaerolineaceae as the major bacteria would have played an important role in the process of fermentation and oxidation of alkanes, and generated small molecules like formate, acetate, hydrogen, carbon dioxide. Finally,
Methanosaeta ultimately metabolized acetate to methane and carbon dioxide through acetoclastic pathway.

\section{Additional files}

Additional file 1: Table S1. Characteristics of primers for quantitative PCR.

\section{Authors' contributions}

BL performed all the experiments assisted by LYW. BL and LYW wrote the manuscript assisted by all co-authors. LYW, BZM, JDG designed the study. SMM assisted BL and LYW on statistical analysis and in the discussion on the interpretation of the data. JFL and SZY were committed to all the experiments. All authors read and approved the final manuscript.

\section{Author details}

${ }^{1}$ State Key Laboratory of Bioreactor Engineering and Institute of Applied Chemistry, East China University of Science and Technology, Shanghai, People's Republic of China. ${ }^{2}$ School of Biological Sciences, The University of Hong Kong, Pokfulam Road, Hong Kong, People's Republic of China. ${ }^{3}$ Shanghai Collaborative Innovation Center for Biomanufacturing Technology, Shanghai 200237, People's Republic of China.

\section{Acknowledgements}

This work was supported by the National Science Foundation of China (No. 31200101, 51174092) and the NSFC/RGC Joint Research Fund (No. 41161160560). 


\section{Compliance with ethical guidelines}

\section{Competing interests}

The authors declare that they have no competing interests.

Received: 23 February 2015 Accepted: 18 May 2015

Published online: 18 June 2015

\section{References}

Abu Laban N, Dao A, Semple K, Foght J (2015) Biodegradation of $C_{7}$ and $\mathrm{C}_{8}$ iso-alkanes under methanogenic conditions. Environ Microbiol. doi:10.1111/1462-2920.12643

Aitken CM, Jones DM, Maguire MJ, Gray ND, Sherry A, Bowler BFJ et al (2013) Evidence that crude oil alkane activation proceeds by different mechanisms under sulfate-reducing and methanogenic conditions. Geochim Cosmochim Ac 109:162-174. doi:10.1016/j.gca.2013.01.031

Allen JP, Atekwana EA, Atekwana EA, Duris JW, Werkema DD, Rossbach S (2007) The microbial community structure in petroleum-contaminated sediments corresponds to geophysical signatures. Appl Environ Microbiol 73(9):2860-2870. doi:10.1128/aem.01752-06

Anderson RT, Lovley DR (2000) Biogeochemistry: hexadecane decay by methanogenesis. Nature 404(6779):722-723

Bakermans C, Madsen EL (2002) Diversity of 165 rDNA and naphthalene dioxygenase genes from coal-tar-waste-contaminated aquifer waters. Microb Ecol 44(2):95-106. doi:10.1007/s00248-002-0005-8

Berdugo-Clavijo C, Gieg LM (2014) Conversion of crude oil to methane by a microbial consortium enriched from oil reservoir production waters. Front Microbiol 5:197. doi:10.3389/fmicb.2014.00197

Berdugo-Clavijo C, Dong X, Soh J, Sensen CW, Gieg LM (2012) Methanogenic biodegradation of two-ringed polycyclic aromatic hydrocarbons. FEMS Microbiol Ecol 81(1):124-133. doi:10.1111/j.1574-6941.2012.01328.x

Callaghan AV (2013) Enzymes involved in the anaerobic oxidation of $n$-alkanes: from methane to long-chain paraffins. Front Microbiol. doi:10.3389/ fmicb.2013.00089

Callaghan AV, Davidova IA, Savage-Ashlock K, Parisi VA, Gieg LM, Suflita JM et al (2010) Diversity of benzyl- and alkylsuccinate synthase genes in hydrocarbon-impacted environments and enrichment cultures. Environ Sci Technol 44(19):7287-7294. doi:10.1021/es1002023

Cheng L, He Q, Ding C, Dai LR, Li Q, Zhang H (2013a) Novel bacterial groups dominate in a thermophilic methanogenic hexadecanedegrading consortium. FEMS Microbiol Ecol 85(3):568-577. doi:10.1111/1574-6941.12141

Cheng L, Ding C, Li Q, He Q, Dai LR, Zhang H (2013b) DNA-SIP reveals that Syntrophaceae play an important role in methanogenic hexadecane degradation. PLoS One 8(7):e66784. doi:10.1371/journal.pone.0066784

Cheng L, Rui JP, Li Q, Zhang H, Lu YH (2013c) Enrichment and dynamics of novel syntrophs in a methanogenic hexadecane-degrading culture from a Chinese oilfield. FEMS Microbiol Ecol 83(3):757-766. doi:10.1111/1574-6941.12031

Dojka MA, Hugenholtz P, Haack SK, Pace NR (1998) Microbial diversity in a hydrocarbon- and chlorinated-solvent-contaminated aquifer undergoing intrinsic bioremediation. Appl Environ Microbiol 64(10):3869-3877

Embree M, Nagarajan H, Movahedi N, Chitsaz H, Zengler K (2014) Singlecell genome and metatranscriptome sequencing reveal metabolic interactions of an alkane-degrading methanogenic community. ISME J 8(4):757-767. doi:10.1038/ismej.2013.187

Ferry JG (1993) Methanogenesis: ecology, physiology, biochemistry and genetics. Chapman \& Hall Microbiology Series. Springer, USA. doi:10.1007/978-1-4615-2391-8

Ficker M, Krastel K, Orlicky S, Edwards E (1999) Molecular characterization of a toluene-degrading methanogenic consortium. Appl Environ Microbiol 65(12):5576-5585

Gieg LM, Duncan KE, Suflita JM (2008) Bioenergy production via microbial conversion of residual oil to natural gas. Appl Environ Microbiol 74(10):30223029. doi:10.1128/aem.00119-08

Gojgic-Cvijovic GD, Milic JS, Solevic TM, Beskoski VP, Ilic MV, Djokic LS et al (2012) Biodegradation of petroleum sludge and petroleum polluted soil by a bacterial consortium: a laboratory study. Biodegradation 23(1):1-14. doi:10.1007/s10532-011-9481-1
Gray ND, Sherry A, Hubert C, Dolfing J, Head IM (2010) Chapter 5-methanogenic degradation of petroleum hydrocarbons in subsurface environments: remediation, heavy oil formation, and energy recovery. In: Laskin Al, Sariaslani S, Geoffrey MG (eds) Advances in applied microbiology, vol 72. Academic Press, New York, pp 137-161. doi:10.1016/ S0065-2164(10)72005-0

Gray ND, Sherry A, Grant RJ, Rowan AK, Hubert CRJ, Callbeck CM et al (2011) The quantitative significance of Syntrophaceae and syntrophic partnerships in methanogenic degradation of crude oil alkanes. Environ Microbiol 13(11):2957-2975. doi:10.1111/j.1462-2920.2011.02570.x

Greene AC, Patel BKC, Sheehy AJ (1997) Deferribacter thermophilus gen. nov., sp. nov., a novel thermophilic manganese- and iron-reducing bacterium isolated from a petroleum reservoir. Int J Syst Bacteriol 47(2):505-509. doi:10.1099/00207713-47-2-505

Guiot SR, Pauss A, Costerton JW (1992) A structured model of the anaerobic granule consortium. Water Sci Technol 25(7):1-10

Head IM, Larter SR, Gray ND, Sherry A, Adams JJ, Aitken CM et al (2010) Hydrocarbon degradation in petroleum reservoirs. In: Timmis K (ed) Handbook of hydrocarbon and lipid microbiology. Springer, Berlin, pp 3097-3109. doi:10.1007/978-3-540-77587-4_232

Herrmann S, Kleinsteuber S, Neu TR, Richnow HH, Vogt C (2008) Enrichment of anaerobic benzene-degrading microorganisms by in situ microcosms. FEMS Microbiol Ecol 63(1):94-106. doi:10.1111/j.1574-6941.2007.00401.x

Hirschler-Réa A, Cravo-Laureau C, Casalot L, Matheron R (2012) Methanogenic octadecene degradation by syntrophic enrichment culture from brackish sediments. Curr Microbiol 65(5):561-567. doi:10.1007/s00284-012-0195-3

Huber T, Faulkner G, Hugenholtz P (2004) Bellerophon: a program to detect chimeric sequences in multiple sequence alignments. Bioinformatics 20(14):2317-2319. doi:10.1093/bioinformatics/bth226

Hug LA, Castelle CJ, Wrighton KC, Thomas BC, Sharon I, Frischkorn KR et al (2013) Community genomic analyses constrain the distribution of metabolic traits across the Chloroflexi phylum and indicate roles in sediment carbon cycling. Microbiome 1(1):22. doi:10.1186/2049-2618-1-22

Jones DM, Head IM, Gray ND, Adams JJ, Rowan AK, Aitken CM et al (2008) Crude-oil biodegradation via methanogenesis in subsurface petroleum reservoirs. Nature 451(7175):176-180. doi:10.1038/nature06484

Kasai Y, Takahata Y, Hoaki T, Watanabe K (2005) Physiological and molecular characterization of a microbial community established in unsaturated, petroleum-contaminated soil. Environ Microbiol 7(6):806-818. doi:10.1111/j.1462-2920.2005.00754.x

Kobayashi H, Endo K, Sakata S, Mayumi D, Kawaguchi H, Ikarashi M et al (2012) Phylogenetic diversity of microbial communities associated with the crude-oil, large-insoluble-particle and formation-water components of the reservoir fluid from a non-flooded high-temperature petroleum reservoir. J Biosci Bioeng 113(2):204-210. doi:10.1016/j. jbiosc.2011.09.015

Kolukirik M, Ince O, Ince B (2011) Increment in anaerobic hydrocarbon degradation activity of halic bay sediments via nutrient amendment. Microbial Ecol 61(4):871-884. doi:10.1007/s00248-011-9825-8

Li W, Wang LY, Duan RY, Liu JF, Gu JD, Mu BZ (2012) Microbial community characteristics of petroleum reservoir production water amended with $n$-alkanes and incubated under nitrate-, sulfate-reducing and methanogenic conditions. Int Biodeter Biodegr 69:87-96. doi:10.1016/j. ibiod.2012.01.005

Magot M, Fardeau ML, Arnauld O, Lanau C, Ollivier B, Thomas P et al (1997) Spirochaeta smaragdinae sp. nov., a new mesophilic strictly anaerobic spirochete from an oil field. FEMS Microbiol Lett 155(2):185-191. doi:10.1111/j.1574-6968.1997.tb13876.x

Mbadinga SM, Li KP, Zhou L, Wang LY, Yang SZ, Liu JF et al (2012) Analysis of alkane-dependent methanogenic community derived from production water of a high-temperature petroleum reservoir. Appl Microbiol Biot 96(2):531-542. doi:10.1007/s00253-011-3828-8

Militon C, Boucher D, Vachelard C, Perchet G, Barra V, Troquet J et al (2010) Bacterial community changes during bioremediation of aliphatic hydrocarbon-contaminated soil. FEMS Microbiol Ecol 74(3):669-681. doi:10.1111/j.1574-6941.2010.00982.x

Nazina TN, Shestakova NM, Grigor'yan AA, Mikhailova EM, Tourova TP, Poltaraus AB et al (2006) Phylogenetic diversity and activity of anaerobic microorganisms of high-temperature horizons of the Dagang oil field (P. R. China). Microbiology 75(1):55-65. doi:10.1134/ S0026261706010115 
Paissé S, Coulon F, Goñi-Urriza M, Peperzak L, McGenity TJ, Duran R (2008) Structure of bacterial communities along a hydrocarbon contamination gradient in a coastal sediment. FEMS Microbiol Ecol 66(2):295-305. doi:10.1111/j.1574-6941.2008.00589.x

Ramos-Padron E, Bordenave S, Lin S, Bhaskar IM, Dong X, Sensen CW et al (2011) Carbon and sulfur cycling by microbial communities in a gypsumtreated oil sands tailings pond. Environ Sci Technol 45(2):439-446. doi:10.1021/es1028487

Riviere D, Desvignes V, Pelletier E, Chaussonnerie S, Guermazi S, Weissenbach J et al (2009) Towards the definition of a core of microorganisms involved in anaerobic digestion of sludge. ISME J 3(6):700-714. doi:10.1038/ ismej.2009.2

Saitou N, Nei M (1987) The neighbor-joining method: a new method for reconstructing phylogenetic trees. Mol Biol Evol 4(4):406-425

Savage KN, Krumholz LR, Gieg LM, Parisi VA, Suflita JM, Allen J et al (2010) Biodegradation of low-molecular-weight alkanes under mesophilic, sulfatereducing conditions: metabolic intermediates and community patterns. FEMS Microbiol Ecol 72(3):485-495. doi:10.1111/j.1574-6941.2010.00866.x

Schlötelburg C, von Wintzingerode F, Hauck R, Hegemann W, Göbel UB (2000) Bacteria of an anaerobic 1,2-dichloropropane-dechlorinating mixed culture are phylogenetically related to those of other anaerobic dechlorinating consortia. Int J Syst Evol Microbiol 50(4):1505-1511. doi:10.1099/00207713-50-4-1505

Sekiguchi Y, Takahashi H, Kamagata Y, Ohashi A, Harada H (2001) In situ detection, isolation, and physiological properties of a thin filamentous microorganism abundant in methanogenic granular sludges: a novel isolate affiliated with a clone cluster, the green non-sulfur bacteria, subdivision I. Appl Environ Microbiol 67(12):5740-5749. doi:10.1128/ aem.67.12.5740-5749.2001

Sherry A, Gray ND, Ditchfield AK, Aitken CM, Jones DM, Röling WFM et al (2013) Anaerobic biodegradation of crude oil under sulphate-reducing conditions leads to only modest enrichment of recognized sulphate-reducing taxa. Int Biodeter Biodegr 81:105-113. doi:10.1016/j.ibiod.2012.04.009

Sherry A, Grant RJ, Aitken CM, Jones DM, Head IM, Gray ND (2014) Volatile hydrocarbons inhibit methanogenic crude oil degradation. Front Microbiol 5:9. doi:10.3389/fmicb.2014.00131

Sun W, Cupples AM (2012) Diversity of five anaerobic toluene-degrading microbial communities investigated using stable isotope probing. Appl Environ Microbiol 78(4):972-980. doi:10.1128/aem.06770-11

Sutton NB, Maphosa F, Morillo JA, Abu Al-Soud W, Langenhoff AAM, Grotenhuis T et al (2013) Impact of long-term diesel contamination on soil microbial community structure. Appl Environ Microbiol 79(2):619-630. doi:10.1128/aem.02747-12

Symons GE, Buswell AM (1933) The methane fermentation of carbohydrates. J Am Chem Soc 55(5):2028-2036. doi:10.1021/ja01332a039

Tamura K, Stecher G, Peterson D, Filipski A, Kumar S (2013) MEGA6: molecular evolutionary genetics analysis version 6.0. Mol Biol Evol 30(12):27252729. doi:10.1093/molbev/mst197

Tan B, Dong X, Sensen CW, Foght J (2013) Metagenomic analysis of an anaerobic alkane-degrading microbial culture: potential hydrocarbonactivating pathways and inferred roles of community members. Genome 56(10):599-611. doi:10.1139/gen-2013-0069

Tan B, de Araújo e Silva R, Rozycki T, Nesbø C, Foght J (2014a) Draft genome sequences of three Smithella spp. obtained from a methanogenic alkanedegrading culture and oil field produced water. Genome Announc. doi:10.1128/genomeA.01085-14

Tan B, Nesbo C, Foght J (2014b) Re-analysis of omics data indicates Smithella may degrade alkanes by addition to fumarate under methanogenic conditions. ISME J. doi:10.1038/ismej.2014.87

Thauer RK (1998) Biochemistry of methanogenesis: a tribute to Marjory Stephenson: 1998 Marjory Stephenson Prize Lecture. Microbiology 144(9):2377-2406. doi:10.1099/00221287-144-9-2377
Tischer K, Kleinsteuber S, Schleinitz KM, Fetzer I, Spott O, Stange F et al (2013) Microbial communities along biogeochemical gradients in a hydrocarbon-contaminated aquifer. Environ Microbiol 15(9):2603-2615. doi:10.1111/1462-2920.12168

Wang LY, Gao CX, Mbadinga SM, Zhou L, Liu JF, Gu JD et al (2011) Characterization of an alkane-degrading methanogenic enrichment culture from production water of an oil reservoir after 274 days of incubation. Int Biodeter Biodegr 65(3):444-450. doi:10.1016/j.ibiod.2010.12.010

Wang LY, Li W, Mbadinga SM, Liu JF, Gu JD, Mu BZ (2012) Methanogenic microbial community composition of oily sludge and its enrichment amended with alkanes incubated for over 500 days. Geomicrobiol J 29(8):716-726. doi:10.1080/01490451.2011.619634

Weisburg WG, Barns SM, Pelletier DA, Lane DJ (1991) 16 S ribosomal DNA amplification for phylogenetic study. J Bacteriol 173(2):697-703

Winderl C, Anneser B, Griebler C, Meckenstock RU, Lueders T (2008) Depthresolved quantification of anaerobic toluene degraders and aquifer microbial community patterns in distinct redox zones of a tar oil contaminant plume. Appl Environ Microbiol 74(3):792-801. doi:10.1128/ aem.01951-07

Yamada T, Sekiguchi Y (2009) Cultivation of uncultured Chloroflexi subphyla: significance and ecophysiology of formerly uncultured Chloroflexi'subphylum I' with natural and biotechnological relevance. Microbes Environ 24(3):205-216. doi:10.1264/jsme2.ME09151S

Yamada T, Sekiguchi Y, Imachi H, Kamagata Y, Ohashi A, Harada H (2005) Diversity, localization, and physiological properties of filamentous microbes belonging to Chloroflexi subphylum I in mesophilic and thermophilic methanogenic sludge granules. Appl Environ Microbiol 71(11):74937503. doi:10.1128/aem.71.11.7493-7503.2005

Yamada T, Imachi H, Ohashi A, Harada H, Hanada S, Kamagata Y et al (2007) Bellilinea caldifistulae gen. nov., sp. nov., and Longilinea arvoryzae gen. nov., sp. nov., strictly anaerobic, filamentous bacteria of the phylum Chloroflexi isolated from methanogenic propionate-degrading consortia. Int J Syst Evol Microbiol 57(10):2299-2306. doi:10.1099/ijs.0.65098-0

Yan T, LaPara TM, Novak PJ (2006) The reductive dechlorination of 2,3,4,5-tetrachlorobiphenyl in three different sediment cultures: evidence for the involvement of phylogenetically similar Dehalococcoides like bacterial populations. FEMS Microbiol Ecol 55(2):248-261. doi:10.1111/j.1574-6941.2005.00022.x

Yu Y, Breitbart M, McNairnie P, Rohwer F (2006) FastGroupll: a web-based bioinformatics platform for analyses of large 16S rDNA libraries. BMC Bioinform 7(1):57. doi:10.1186/1471-2105-7-57

Zengler K, Richnow HH, Rossello-Mora R, Michaelis W, Widdel F (1999) Methane formation from long-chain alkanes by anaerobic microorganisms. Nature 401(6750):266-269

Zhou L, Li KP, Mbadinga SM, Yang SZ, Gu JD, Mu BZ (2012) Analyses of $n$-alkanes degrading community dynamics of a high-temperature methanogenic consortium enriched from production water of a petroleum reservoir by a combination of molecular techniques. Ecotoxicology 21(6):1680-1691. doi:10.1007/s10646-012-0949-5

\section{Submit your manuscript to a SpringerOpen ${ }^{\odot}$ journal and benefit from:}

- Convenient online submission

- Rigorous peer review

- Immediate publication on acceptance

- Open access: articles freely available online

- High visibility within the field

- Retaining the copyright to your article

Submit your next manuscript at $>$ springeropen.com 